\title{
ARACHIDONIC ACID METABOLISM IN MURINE FIBROSARCOMA CELLS WITH DIFFERING IN VIVO AND IN VITRO CHARACTERISTICS
}

\author{
Suzanne E. G. Fligiel, Patricia Perone and James Varani ${ }^{1}$ \\ Department of Pathology, University of Michigan, Medical School, Ann Arbor, MI 48109, USA.
}

\begin{abstract}
Arachidonic acid metabolism was examined in a series of strongly malignant murine fibrosarcoma cell lines and in a series of weakly malignant lines isolated from the same tumors. The cells were examined in the unstimulated state and after stimulation with 12 0-tetradecanoyl phorbol acetate (TPA), laminin or fibronectin. All 3 agents were known from previous studies to induce adherence and motility in the murine fibrosarcoma cells. When the cells were prelabelled with ${ }^{3} \mathrm{H}$-arachidonic acid, all 3 agents stimulated the release of radioactivity into the supernatant fluids. The response to TPA was rapid while the response was slower but sustained when either laminin or fibronectin was used as the stimulating agent. This is of interest because TPA induces a rapid but transient adherence response in the same cells while laminin and fibronectin induce a slow, sustained response. Examination by radioimmunoassay procedures indicated that both control cells and stimulated cells were able to produce a variety of lipoxygenase and cyclooxygenase metabolites. In quantitative terms, the strongly malignant cells were more active than their weakly malignant counterparts. They released greater amounts of radioactivity into the supernatant fluid and produced a greater quantity of arachidonic acid metabolites, particularly prostaglandin $E_{2}$, than did the corresponding weakly malignant cells. This is of interest because previous studies have shown that while both the strongly and weakly malignant cells respond in the adherence assay to TPA, laminin and fibronectin, only the strongly malignant cells demonstrate directional motility (chemotaxis and haptotaxis).
\end{abstract}

Arachidonic acid metabolism accompanies stimuluscoupled responses in several types of cells (Habenicht et al., 1981; Schrey and Rubin, 1979; Butler-Gralla et al., 1983; Wertz and Mueller 1978, 1980; Levine and Hassid, 1977) and has been extensively investigated in leukocytes (see Goldman and Goetzl, 1983 for a review). When leukocytes are stimulated with chemotactic factors, arachidonic acid is released from phospholipid pools and is metabolized through both the lipoxygenase and cyclooxygenase pathways. Products of the lipoxygenase pathway (including monohydroxyeicosatetraenoic acids [HETEs] and leukotrienes [LTs]) are thought to be positive mediators of the chemotactic response as these agents will stimulate cell-to-substrate adherence, cell-to-cell aggregation, enzyme release and chemotaxis in leukocytes (Goldman and Goetzl, 1983). Cyclooxygenase products (i.e., prostaglandins [PGs]), on the other hand, are thought to serve as negative modulators, limiting the cellular response to stimulation (O'Flaherty et al., 1979; Rivkin et al., 1975; Kunkel et al., 1979; Fantone et al., $1983 b$ ). Arachidonic acid metabolites may play a role in the chemotactic response of non-leukocytic cells as well. Mensing and Czarnetski (1984) showed that LTB $_{4}$ was chemotactic for normal fibroblasts and studies in our laboratory showed that the same agent stimulated adhesiveness in Walker carcinosarcoma cells (Varani, 1985). The response in the Walker cells was very similar to that stimulated by chemotactic peptides.
Other studies have shown that cyclooxygenase metabolites (i.e., E-series prostaglandins and prostacyclin) inhibit chemotactic factor-induced adherence and chemotaxis in the same Walker cells (Fantone et al., 1983a; Mokashi et al., 1983; Varani and Perone, 1985).

In the present studies we investigated arachidonic acid metabolism in a series of strongly and weakly malignant murine fibrosarcoma cells. The cells were examined in the unstimulated state and following stimulation with 3 different ligands (i.e., 12-0-tetradecanoyl phorbol acetate [TPA], laminin and fibronectin) that induce adherence and motility in these and other cells (Lowe et al., 1978; Yamasaki et al., 1979; Castagna et al., 1979; Koffler et al., 1981; Schor et al., 1981; Gauss-Muller et al., 1980; McCarthy et al., 1983, 1984; Varani and Fantone, 1982; Lee et al., 1984; Situ et al., 1984; Varani et al., 1985a,b). All 3 ligands induced the release of ${ }^{3} \mathrm{H}$-arachidonic acid from prelabelled cells and a conversion of arachidonic acid into a variety of end products. These results show that in the murine fibrosarcoma cells, as in several other cell types previously investigated (Butler-Gralla et al., 1983; Levine and Hassid, 1977; Wertz and Mueller, 1980) metabolism of arachidonic acid accompanies response to stimulation with TPA. They show, furthermore, that laminin and fibronectin-high-molecularweight glycoproteins which may have a very different mode of action from TPA-also stimulate arachidonic acid metabolism in responsive cells.

\section{MATERIAL AND METHODS}

\section{Cells}

The strongly and weakly malignant cell lines used in this study were obtained from three different chemically-induced murine fibrosarcomas. The tumors from which the cell lines arose have been designated as tumors 1.0, 1.1 and 1.2. The strongly malignant cell lines have been designated 1.0/L1, 1.1, 1.1/clone 16, and 1.2. Weakly malignant cell lines were obtained from each of the 3 tumors. These cell lines have been designated as $1.0 /$ anti- $\mathrm{B}^{\mathbf{r}}, 1.1$ /anti- $\mathrm{B}^{\mathbf{r}}$, and 1.2 /anti- $\mathrm{B}^{\mathbf{r}}$. The isolation and characterization of these populations have been described in previous reports (Varani et al., $1979 a, b, 1980,1983 b)$. In the present study, all of the cell lines were maintained under identical conditions which included growth in RPMI-1640 medium supplemented with $10 \%$ fetal bovine serum at $37^{\circ} \mathrm{C}$ in $5 \%$ $\mathrm{CO}_{2} / 95 \%$ air. The cells were subcultured by trypsinization as necessary. Prior to use in these studies all of the cell lines were shown to be free of mycoplasma contamination by incubation in mycoplasma broth and on mycoplasma agar.

\footnotetext{
'To whom reprint requests should be sent.
} 


\section{Stimulating agents}

Two large glycoprotein molecules, laminin and fibronectin, were used as stimulating agents in this study. Laminin was prepared in our laboratory by the method of Timpl et al. (1979) or purchased from Bethesda Research (Gaithersburg, MD). The commercially obtained reagent was also purified by the same method. Purity of the laminin was checked by SDS-polyacrylamide gel $(5 \%)$ electrophoresis run under reducing conditions. Only 2 major protein bands-at $\mathbf{M}^{\mathrm{r}}=$ 200,000 and 400,000 - were seen. When examined by means of an enzyme-linked immunosorbent assay (ELISA) (Varani et al., 1983a), the laminin reacted with anti-laminin antibodies undiluted or at dilutions up to $1: 1,000,000$ but did not react with anti-fibronectin antibodies (provided as a gift by Dr. R. Wiggins, Department of Medicine, University of Michigan) or with anti-type IV collagen antibodies (provided as a gift by Dr. H. Furthmayr, Department of Pathology, Yale University). When a cell attachment assay was used as an indicator of biological activity (Varani $e t$ $a l ., 1983 a$ ), the laminin was effective at $0.5-1.0 \mu \mathrm{g}$ per 35-mm diameter dish.

Human plasma fibronectin was purchased from $\mathrm{Be}-$ thesda Research or from Sigma (St. Louis, MO). Both commercial preparations showed a single major protein band when examined by SDS-polyacrylamide gel electrophoresis. The fibronectin preparations reacted with anti-fibronectin antibodies by ELISA but did not react with the anti-laminin antibodies. Cell attachment activity was detectable with concentrations as low as 2 $\mu \mathrm{g}$ per 35-mm dish.

We also used the biologically-active phorbol ester, 12-0-tetradecanoyl phorbol acetate (TPA) as a stimulating agent. The TPA was obtained from Sigma and frozen as a $1.6 \times 10^{-2} \mathrm{M}$ solution in dimethylsulfoxide. It was diluted in culture medium at the time of use.

\section{Arachidonic acid metabolism}

${ }^{3} \mathrm{H}$-arachidonic acid $(87 \mathrm{Ci} / \mathrm{mmol})$, obtained from New England Nuclear, Boston, MA, was used to measure arachidonic acid release from the control and stimulated cells. Freshly-harvested cells were labelled by preincubation for $2 \mathrm{hr}$ with $1 \mu \mathrm{Ci}$ of the ${ }^{3} \mathrm{H}$-arachidonic acid per $5 \times 10^{7}$ cells in $5 \mathrm{ml}$ RPMI- 1640 culture medium supplemented with $10 \%$ fetal bovine serum. Incubation was carried out at $37^{\circ} \mathrm{C}$ and $5 \% \mathrm{CO}_{2}$. During the labelling procedure, the cells were kept in tubes and maintained in suspension by gentle shaking. The distribution of the radioactivity within the labelled cells was determined by subjecting the labelled cells to a Folch extraction (Folch et al., 1957) and analyzing the chloroform-soluble fraction by thin-layer chromatography using a modification of the solvent system described by Skipski et al. (1964). Depending on the cell type and the experiment, we were able to obtain $1-2 \times 10^{5}$ counts per minute (CPM) of ${ }^{3} \mathrm{H}$-arachidonic acid incorporated per $1 \times 10^{6}$ cells. Nearly all of the incorporated material was found in the chloroformsoluble phase and when this material was analyzed, the radioactivity was found in bands co-migrating with phosphatidylcholine, phosphatidylinositol, phosphatidylserine and phosphatidylethanolamine. Less than $10 \%$ of the chloroform-soluble radioactivity was in bands which co-migrated with free fatty acids, triglycerides and cholesterol esters. After labelling, the cells were centrifuged and washed twice in culture medium to remove unincorporated ${ }^{3} \mathrm{H}$-arachidonic acid. The cells were then aliquoted into tubes, stimulated with the appropriate agent and incubated at $37^{\circ} \mathrm{C}$ and $5 \%$ $\mathrm{CO}_{2}$. At various times thereafter, 200- $\mu$ l samples $(2 \times$ $10^{6}$ cells) were removed from the tubes. The samples were added to $300 \mu \mathrm{l}$ of phosphate-buffered saline and the cells separated from the supernatant fluid by centrifugation. Radioactivity in the supernatant fluid was then determined using a $\beta$-scintillation counter.

Cyclooxygenase and lipoxygenase metabolites of arachidonic acid were quantitated in the control and stimulated cells. The cyclooxygenase products measured were $\mathrm{PGE}_{2}, \mathrm{PGF}_{2 \alpha}$, and 6-keto $\mathrm{PGF}_{1, x}$ (a prostacyclin metabolite). Lipoxygenase products measured included 5-HETE, 12-HETE and $\mathrm{LTC}_{4}$. For these assays, the cells were harvested, washed 4 times in serum-free culture medium and incubated at $5 \times 10^{6}$ cells per $\mathrm{ml}$ of serum-free medium. At various subsequent times, the supernatant fluids (for cyclooxygenase metabolites) or the cells and supernatant fluids (for lipoxygenase products) were harvested, extracted and assayed. The extraction procedure involved precipitation of the protein with acetonitrile, and extraction of most neutral lipids from the acidified acetonitrile fraction with petroleum ether. After removal of the ether layer, the remaining aqueous phase was extracted twice with ethyl acetate and dried in air. The residue was redissolved in phosphate-buffered saline containing $0.1 \%$ gelatin and assayed for the various metabolites using radioimmunoassay (RIA) procedures. Assays for cyclooxygenase metabolites were performed with antibodies and labelled ligands obtained from NEN. The limits of sensitivity for the 3 assays were $0.9-3.8 \mathrm{pg} /$ tube. Cross-reactivity of each antibody to related prostaglandins was low (less than $1.8 \%$ ). The $\mathrm{LTC}_{4}$ assay was also carried out using a NEN assay kit. The limit of sensitivity for this assay was $3.7 \mathrm{pg} /$ reaction tube. The antibody to $\mathrm{LTC}_{4}$ cross-reacted with $\mathrm{LTD}_{4}(55 \%)$ and $\mathrm{LTE}_{4}(8.6 \%)$ but showed low cross-reactivity (less than $1 \%$ ) with $\mathrm{LTB}_{4}$, mono-HETEs and various prostaglandins. The 5-HETE and 12-HETE assays were carried out with kits available from Seragen (Boston, MA). The limit of sensitivity of the 5-HETE assay was $8 \mathrm{pg} / \mathrm{reaction}$ tube. The antibody used in this assay cross-reacted with 5,15-DiHETE $(10 \%)$ and to a lesser extent (3-5\%) with $\mathrm{LTB}_{4}, \mathrm{LTC}_{4}, \mathrm{LTD}_{4}$ and $\mathrm{LTE}_{4}$ but showed low cross-reactivity (less than $0.6 \%$ ) with other mono-HETEs and various prostaglandins. The 12HETE assay had a limit of sensitivity of $2 \mathrm{pg} /$ reaction tube but showed extremely low cross-reactivity (less than $0.3 \%$ ) with other mono-HETES, leukotrienes and prostaglandins. The actual assay procedures were carried out by the Ligand Core Laboratory at the Michigan Diabetes Research and Training Center (Ann Arbor, MI).

\section{RESULTS}

\section{Arachidonic acid metabolism in the strongly and weakly malignant cells}

Cells were prelabelled with ${ }^{3} \mathrm{H}$-arachidonic acid as described in "Material and Methods." They were then examined for their ability to release radioactivity into the culture medium under unstimulated conditions and after stimulation with laminin, fibronectin or TPA (Fig. 1). In the absence of stimulation there was a slow release of radioactivity into the culture medium from all of the cells. The amount of radioactivity found in 

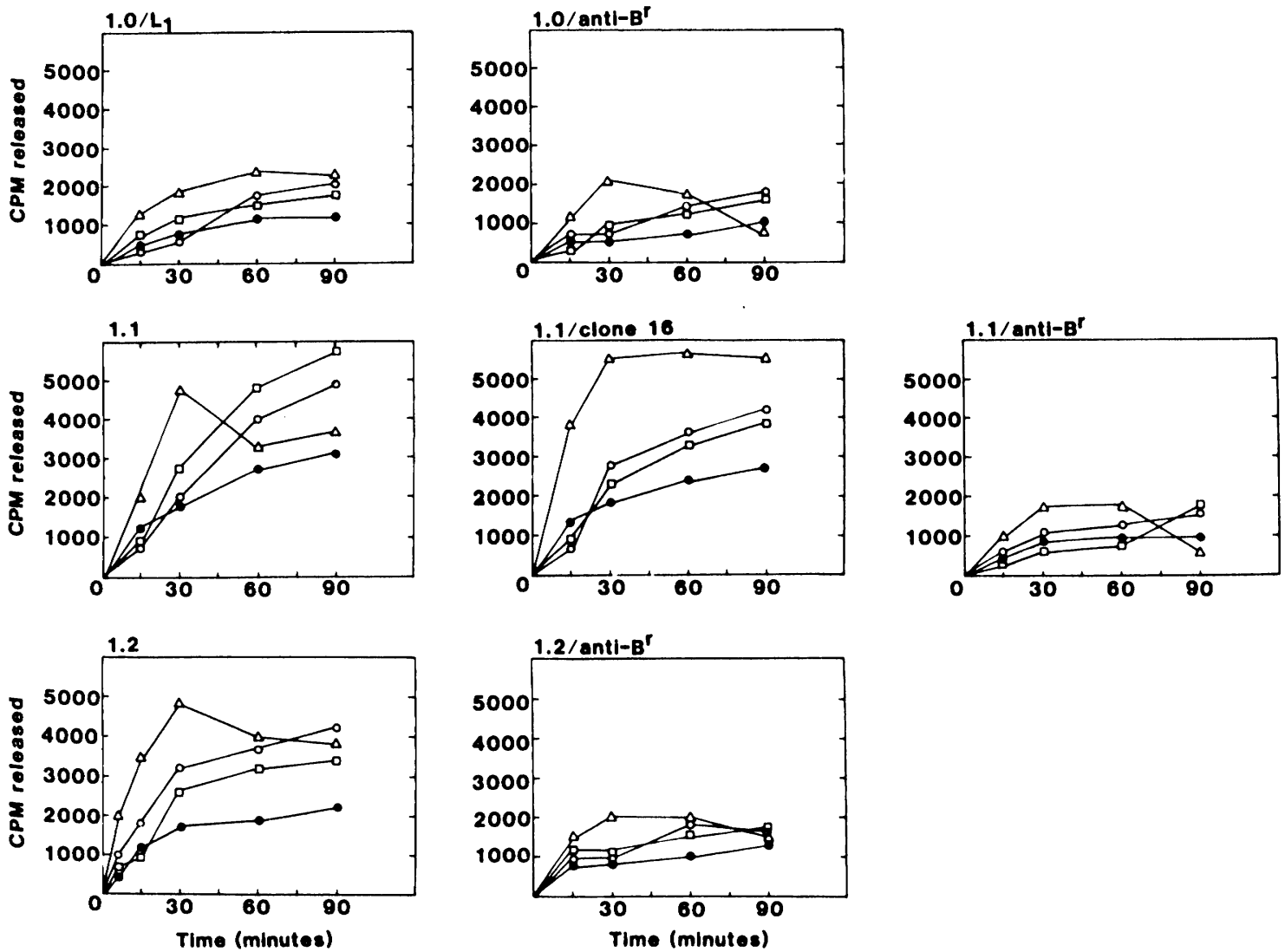

FIGURE 1 - Release of radioactivity from ${ }^{3} \mathrm{H}$-arachidonic acid-prelabelled cells. The cells were pretreated with ${ }^{3} \mathrm{H}$-arachidonic acid as described in "Material and Methods" and then incubated in culture medium with and without stimulation. The values shown are the amount of radioactivity recovered from the supernatant fluid at various subsequent times. Values are averages of duplicate tubes in a single experiment where the duplicate values were nearly always within $10 \%$ of the mean values. Cells from each tumor were examined together between 3-7 times with very similar results. (Unstimulated, $-0 ; 1.6 \times 10^{-8} \mathrm{M}$ TPA, $\triangle-\triangle ; 100 \mu \mathrm{g} / \mathrm{ml}$ laminin, $\bigcirc-O ; 100 \mu \mathrm{g} / \mathrm{ml}$ fibronectin, $\left.\square-\square\right)$.

the supernatant fluid increased over the 90 -min observation period and accounted for $0.5-1.5 \%$ of the total. With cell lines from 2 of the 3 tumors $(1.1$ and 1.2$)$ the strongly malignant cells were much more active than their weakly malignant counterparts. With the third tumor (1.0), both the strongly and weakly malignant cells released comparable amounts of radioactivity-similar to the amounts released by the weakly malignant cells from the other 2 tumors.

Stimulation of the prelabelled cells with either laminin, fibronectin or TPA led to an increased release of radioactivity into the supernatant fluids from all cells (Fig. 1). With laminin and fibronectin, significant differences between the treated and control cells were not observed at the earliest time points ( 5 and $15 \mathrm{~min}$ ) but were observed after longer incubation $(30,60$ and 90 min). TPA also stimulated arachidonic acid release from all of the cell types. The pattern, however, was different from that observed with laminin and fibronectin. The radioactivity released from the TPA-stimulated cells reached a peak early $(30 \mathrm{~min}$ after stimulation) and then either levelled off or decreased. The decrease in extracellular radioactivity could indicate reincorporation of the released arachidonic acid or a metabolite produced from it.

Radioimmunoassay procedures were used to quantitate arachidonic acid metabolites produced by the various cell lines. For this purpose, the cells were har- vested from culture and incubated under serum-free conditions with or without stimulation for $4 \mathrm{hr}$. The supernatant fluids (for cyclooxygenase metabolites) or the cells and supernatant fluids (for lipoxygenase metabolites) were then extracted as described in "Material and Methods." Cyclooxygenase data are shown in Table I and lipoxygenase data in Table II. To summarize the results of the cyclooxygenase analyses, $\mathrm{PGE}_{2}$ was the major metabolite identified with all of the cells, although significant amounts of 6-keto $\mathrm{PGF}_{1}$ and $\mathrm{PGF}_{2 \alpha}$ were also detected. The quantities of metabolites produced by the cells varied with cell type and reflected the amounts of radioactivity released from prelabelled cells (compare Table I and Fig. 1). The strongly malignant cells from tumor 1.0 produced slightly higher levels of prostaglandins than did the weakly malignant cells from the same tumor. The strongly malignant cells from the other 2 tumors produced much higher levels than the corresponding weakly malignant cells.

In regards to lipoxygenase metabolites, there were no consistent or dramatic differences between the strongly and weakly malignant cells (Table II). The amount of $\mathrm{LTC}_{4}$ obtained from the strongly malignant cells in the unstimulated state was slightly greater than the amount obtained from the corresponding weakly malignant cells. The relative magnitudes of the differences were much smaller than those observed in the 
TABLE I - CYCLOOXYGENASE METABOLITES OF ARACHIDONIC ACID PRODUCED BY THE STRONGLY AND WEAKLY MALIGNANT CELLS

\begin{tabular}{|c|c|c|c|c|}
\hline \multirow[t]{2}{*}{ Cell line } & \multirow[t]{2}{*}{ Stimulation } & \multicolumn{3}{|c|}{$\begin{array}{c}\text { Amount produced } \\
\left(\mathrm{ng} / 5 \times 10^{6} \text { cells } / 4 \mathrm{hr}\right)^{\prime}\end{array}$} \\
\hline & & $\mathrm{PGE}_{2}$ & 6-keto $\mathrm{PGF}_{1 x}$ & $\mathrm{PGF}_{2,}$ \\
\hline \multirow[t]{4}{*}{$1.0 / \mathrm{L} 1$} & None & $5.7 \pm 0.2$ & $0.7 \pm 0.1$ & $0.6 \pm 0.1$ \\
\hline & $\mathrm{TPA}^{2}$ & $5.6 \pm 0.1$ & $2.5 \pm 0.5$ & $0.6 \pm 0.1$ \\
\hline & Laminin $^{3}$ & $3.6 \pm 0.3$ & $0.5 \pm 0.1$ & $0.2 \pm 0.2$ \\
\hline & Fibronectin ${ }^{4}$ & $1.5 \pm 0.2$ & $0.5 \pm 0.1$ & $0.1 \pm 0.1$ \\
\hline \multirow[t]{4}{*}{$1.0 /$ anti-B $^{r}$} & None & $4.1 \pm 0.3$ & $<0.1$ & $0.4 \pm 0.2$ \\
\hline & TPA & $5.6 \pm 0.4$ & $<0.1$ & $0.6 \pm 0.1$ \\
\hline & Laminin & $12.2 \pm 0.6$ & $<0.1$ & $1.1 \pm 0.3$ \\
\hline & Fibronectin & $14.3 \pm 0.4$ & $<0.1$ & $0.5 \pm 0.1$ \\
\hline \multirow[t]{4}{*}{1.1} & None & $22.3 \pm 1.3$ & $1.8 \pm 0.1$ & $5.1 \pm 0.8$ \\
\hline & TPA & $21.1 \pm 1.0$ & $2.6 \pm 0.3$ & $4.8 \pm 1.3$ \\
\hline & Laminin & $18.6 \pm 0.9$ & $1.5 \pm 0.2$ & $3.8 \pm 0.8$ \\
\hline & Fibronectin & $29.3 \pm 0.7$ & $1.8 \pm 0.2$ & $3.5 \pm 2.0$ \\
\hline \multirow[t]{4}{*}{$1.1 /$ clone 16} & None & $32.0 \pm 3.1$ & $2.1 \pm 0.3$ & $3.5 \pm 0.6$ \\
\hline & TPA & $35.5 \pm 1.9$ & $2.0 \pm 0.4$ & $3.8 \pm 0.7$ \\
\hline & Laminin & $39.7 \pm 1.6$ & $2.6 \pm 0.3$ & $3.7 \pm 1.2$ \\
\hline & Fibronectin & $27.4 \pm 1.0$ & $2.4 \pm 0.2$ & $4.4 \pm 0.7$ \\
\hline \multirow[t]{4}{*}{ 1.1/anti-B ${ }^{r}$} & None & $3.9 \pm 0.9$ & $<0.1$ & $0.1 \pm 0.1$ \\
\hline & TPA & $4.4 \pm 1.7$ & $<0.1$ & $0.2 \pm 0.1$ \\
\hline & Laminin & $2.3 \pm 1.0$ & $<0.1$ & $0.1 \pm 0.1$ \\
\hline & Fibronectin & $5.0 \pm 1.7$ & $<0.1$ & $0.1 \pm 0.1$ \\
\hline \multirow[t]{4}{*}{1.2} & None & $12.8 \pm 1.5$ & $4.2 \pm 0.5$ & $0.5 \pm 0.1$ \\
\hline & TPA & $24.4 \pm 2.3$ & $1.1 \pm 0.1$ & $0.5 \pm 0.1$ \\
\hline & Laminin & $13.0 \pm 1.0$ & $1.5 \pm 0.1$ & $0.7 \pm 0.1$ \\
\hline & Fibronectin & $11.7 \pm 1.3$ & $1.7 \pm 0.2$ & $0.5 \pm 0.1$ \\
\hline \multirow[t]{4}{*}{ 1.2/anti-B ${ }^{r}$} & None & $1.4 \pm 0.2$ & $<0.1$ & $0.1 \pm 0.1$ \\
\hline & TPA & $2.3 \pm 0.3$ & $<0.1$ & $0.1 \pm 0.1$ \\
\hline & Laminin & $1.7 \pm 0.1$ & $<0.1$ & $0.2 \pm 0.1$ \\
\hline & Fibronectin & $1.7 \pm 0.1$ & $<0.1$ & $0.2 \pm 0.1$ \\
\hline
\end{tabular}

'Values shown are averages \pm standard errors of the mean. PGE 2 values for the 1.2 and $1.2 /$ anti-B' cells are based on 6 independent experiments. Other values are based on 3 independent experiments. $-{ }^{2} 1.6 \times 10^{-8} \mathrm{M}$. $-{ }^{3} \mathrm{l} 00 \mu \mathrm{g}$ per $\mathrm{ml} .-{ }^{4} 100 \mu \mathrm{g}$ per $\mathrm{ml}$.

TABLE II - LIPOXYGENASE METABOLITES OF ARACHIDONIC ACID PRODUCED BY THE STRONGLY AND WEAKLY MALIGNANT CELLS

\begin{tabular}{|c|c|c|c|c|}
\hline \multirow[t]{2}{*}{ Cell line } & \multirow[t]{2}{*}{ Stimulation } & \multicolumn{3}{|c|}{$\begin{array}{c}\text { Amount produced } \\
\left(\mathrm{pg} / 5 \times 10^{6} \text { cells } / 4 \mathrm{hr}\right)^{\prime}\end{array}$} \\
\hline & & 5-HETE & 12-HETE & LTC $_{4}$ \\
\hline \multirow[t]{4}{*}{$1.0 / \mathrm{Ll}$} & None & $\mathrm{ND}^{5}$ & ND & $196 \pm 66$ \\
\hline & $\mathrm{TPA}^{2}$ & ND & ND & $172 \pm 80$ \\
\hline & Laminin $^{3}$ & ND & ND & $1,790 \pm 18$ \\
\hline & Fibronectin $^{4}$ & ND & ND & $1,517 \pm 99$ \\
\hline \multirow{4}{*}{$\begin{array}{l}1.0 / \\
\text { anti-B }\end{array}$} & None & ND & ND & $105 \pm 76$ \\
\hline & TPA & ND & ND & $205 \pm 64$ \\
\hline & Laminin & ND & ND & $752 \pm 108$ \\
\hline & Fibronectin & ND & ND & $2,820 \pm 251$ \\
\hline \multirow[t]{4}{*}{1.1} & None & ND & ND & $263 \pm 82$ \\
\hline & TPA & ND & ND & $177 \pm 54$ \\
\hline & Laminin & ND & ND & $148 \pm 44$ \\
\hline & Fibronectin & ND & ND & $109 \pm 70$ \\
\hline \multirow{4}{*}{$\begin{array}{l}1.1 / \\
\text { clone } 16\end{array}$} & None & ND & ND & $138 \pm 66$ \\
\hline & TPA & ND & ND & $1,210 \pm 132$ \\
\hline & Laminin & ND & ND & $169 \pm 70$ \\
\hline & Fibronectin & ND & ND & $162 \pm 76$ \\
\hline \multirow{4}{*}{$\begin{array}{l}1.1 / \\
\text { anti-B }\end{array}$} & None & ND & ND & $104 \pm 62$ \\
\hline & TPA & ND & ND & $252 \pm 73$ \\
\hline & Laminin & ND & ND & $266 \pm 70$ \\
\hline & Fibronectin & ND & ND & $1,210 \pm 140$ \\
\hline \multirow[t]{4}{*}{1.2} & None & $31 \pm 7$ & $20 \pm 1$ & $253 \pm 75$ \\
\hline & TPA & $43 \pm 3$ & $45 \pm 11$ & $1,070 \pm 140$ \\
\hline & Laminin & $46 \pm 2$ & $74 \pm 8$ & $212 \pm 78$ \\
\hline & Fibronectin & ND & ND & $175 \pm 24$ \\
\hline \multirow{4}{*}{$\begin{array}{l}1.2 / \\
\text { anti-B }\end{array}$} & None & $51 \pm 3$ & $<10$ & $173 \pm 161$ \\
\hline & TPA & $58 \pm 10$ & $<10$ & $63 \pm 71$ \\
\hline & Laminin & $85 \pm 7$ & $30 \pm 5$ & $221 \pm 73$ \\
\hline & Fibronectin & ND & ND & $137 \pm 72$ \\
\hline
\end{tabular}

'Values shown are average \pm the differences between mean values and individual values in a single experiment. The metabolites were measured on two separate occasions with sirnilar results. ${ }^{2} 1.6 \times 10^{-8} \mathrm{M} .-^{3} 100 \mu \mathrm{g}$ per ml. ${ }^{4} 100 \mu \mathrm{g}$ per $\mathrm{ml} .{ }^{5}$ Not done. arachidonic acid release studies and assays for prostaglandin production. Likewise, no consistent pattern was seen with any of the 3 stimulating agents. In some instances, there was a dramatic stimulation of $\mathrm{LTC}_{4}$ production (for example in the $1.0 / \mathrm{Ll}$ and $1.0 / \mathrm{anti}^{\mathrm{i}}-\mathrm{B}^{\mathrm{r}}$ cells treated with laminin or fibronectin) but in other instances, the same agent had no effect or actually resulted in a decrease in production (for example, in the 1.1 cells).

\section{DISCUSSION}

Arachidonic acid metabolism has been extensively investigated in relation to leukocyte chemotaxis. When leukocytes are stimulated with chemotactic factors, there is a release of arachidonic acid from phospholipid pools and a stimulation of arachidonic acid metabolism through the lipoxygenase and cyclooxygenase pathways. Several of the arachidonic acid metabolites produced as a result of stimulation have potent mediator function and are thought to play a role in the biological responses to chemotactic stimulation (Goldman and Goetzl, 1983). Although most other systems have not been as widely investigated as leukocytes, arachidonic acid metabolism is known to accompany stimulus-coupled responses in a variety of cells (Habenicht et al., 1981; Schrey and Rubin, 1979; ButlerGralla et al., 1983; Wertz and Mueller, 1980; Levine and Hassid, 1977).

In the present study we investigated arachidonic acid metabolism in a series of murine fibrosarcoma cell lines. The cells that were used included 4 strongly malignant lines from 3 different carcinogen-induced tumors and 3 weakly malignant variant lines isolated 
from the same 3 tumors. The cells were examined in the unstimulated state and after treatment with laminin, fibronectin or TPA. All 3 agents stimulated increased arachidonic acid release from prelabelled cells. With TPA the response was rapid while a slower but sustained response was observed with laminin and fibronectin. This is of interest because a very similar relationship exists in regard to biological responses. In these tumor cells (Varani et al., 1985a) TPA induces a rapid but transient adherence response but has no longterm effect on either cell attachment or spreading. In contrast, both laminin and fibronectin induce a slow but sustained increase in cell attachment and spreading (Varani et al., 1985a,b). Thus, the kinetics of the biological response to the stimulating agents and the kinetics of arachidonic acid release stimulated by the same agents are in accord. This allows for the speculation that the 2 are related. Whether specific metabolites of arachidonic acid are essential mediators of the biological responses induced by these 3 agents remains to be seen. This will have to await a more complete qualitative and quantitative assessment of the metabolites produced by the cells and a direct demonstration that these metabolites can elicit biological responses similar to those produced by the stimulating agents. This has not yet been done although previous studies have shown that products of the lipoxygenase system stimulate adhesiveness in the Walker 256 carcinosar- coma cells (Varani, 1985) and chemotaxis in fibroblasts (Mensing and Czarnetski, 1984).

During the course of our studies it became clear that the strongly malignant cells were metabolically more active with regard to arachidonic acid metabolism than their weakly malignant counterparts. What makes these differences of interest is the observation that similar differences exist in regard to cell motility. The strongly malignant cells are much more motile than the weakly malignant ones. This is observed in the absence of a gradient (Situ et al., 1984) as well as in the presence of a chemotactic or haptotactic gradient (Orr et al., 1981; Varani et al., 1985a). It is interesting, furthermore, that when the strongly malignant cells from the 3 different tumors are compared among themselves, the 1.0/L1 cells are less motile than the other 3 lines (Situ et al., 1984; Varani et al., 1985a). Thus, while there appears to be no precise quantitative relationship between arachidonic acid metabolism and a response in the adherence assay, such a relationship may indeed exist between arachidonic acid metabolism and cell motility.

\section{ACKNOWLEDGEMENT}

This study was supported in part by grant CA 36132 from the USPHS.

\section{REFERENCES}

Butler-Gralla, E., Tapliz, S., and Herschman, H.R., 12-0tetradecanoyl phorbol-13-acetate stimulates release of arachidonic acid, prostaglandin $E_{2}$ and prostaglandin $F_{2} \alpha$ from TPA nonproliferative variants of 3T3 cells. Biochem. biophys. Res. Commun., 111, 194-199 (1983).

Castagna, M., Rochette-Egly, C., and Rosenfeld, C., Tumor promoting phorbol diester induces substrate adhesion and growth inhibition in lymphoblastoid cells. Cancer Lett., 6, 227-234 (1979).

Fantone, J.C., Elgas, L.J., Weinberger, L., and Varani, J., Modulation of tumor cell adherence by prostaglandins. Oncol$o g y, 40,421-426$ (1983a).

Fantone. J.C., Marasco. W.A., Elgas, L.J., and Ward, P.A., Anti-inflammatory effects of prostaglandin $\mathrm{E}_{l}$ : In vivo modulation of the formyl peptide chemotactic receptor on the rat neutrophil. J. Immunol., 130, 1495-1497 (1983b).

FOlCh. J., LeES. M., and SloANE. S.G.H., A simple method for the isolation and purification of total lipids from animal tissues. J. biol. Chem., 226, 497-509 (1957).

Gauss-Muller. V., Kleinman, H.K., Martin. G.R., and SchiffmanN, E., Role of attachment factors and attractants in fibroblast chemotaxis. J. Lab. clin. Med., 96, 1071-1080 (1980).

Goldman, D.W., and GoETzL, E.J., Mediation and modulation of immediate hypersensitivity and inflammation by products of the oxygenation of arachidonic acid. In: P.A. Ward (ed.), Immunology of inflammation; Handbook of inflammation, Vol. 4, pp. 163-187, Elsevier, Amsterdam (1983).

Habenicht, A.J.R., Glomset, J.A., King, W.C., Nist, C., Mitchel, C.D., and Ross, R., Early changes in phosphatidylinositol and arachidonic acid metabolism in quiescent Swiss 3T3 cells stimulated to divide by platelet-derived growth factor. $J$. biol. Chem., 256, 12329-12335 (1981).

Koffler, H.P., Bar-Eli, M., and Territo, M.C., Phorbol ester effect on differentiation of human myeloid leukemia cell lines blocked at different stages of maturation. Cancer Res. ,41, 919926 (1981).

Kunkel, S.L., Thrall, R.T., Kunkel, R.G., Ward, P.A., and ZURIER, R.B., Suppression of immune complex vasculitis by prostaglandins. J. clin. Invest., 64, 1525-1530 (1979).

Lee, E.C., Situ, R., Fantone, J.C., and Varani. J., Functional responses of tumor cells to phorbol esters: role for prostaglandins. Oncology, 41, 210-216 (1984).
LEVINE, L., and HASSID, A., Effects of phorbol-12,13-diesters on prostaglandin production and phospholipase activity in canine kidney (MDCK) cells. Biochem. biophys. Res. Commun.,79, 477-484 (1977).

Lowe, M.E., Pacifici, M., and Holtziner, H., Effect of phorbol12-myristate-13-acetate on the phenotypic program of cultured chondroblasts and fibroblasts. Cancer Res., 38, 2350-2356 (1978).

MCCARThy, J.B., and Furcht, L.T., Laminin and fibronectin promote the haptotactic migration of B 16 mouse melanoma cells in vitro. J. Cell Biol., 98, 1474-1480 (1984).

McCarthy. J.B., Palm, S.L., and FurCht, L.T., Migration by haptotaxis of a Schwann cell tumor line to the basement membrane glycoprotein, laminin. J. Cell Biol., 97, 772-777 (1983).

Mensing. H., and CZARNETSKI. B.M., Leukotriene $B_{4}$ induces in vitro fibroblast chemotaxis. J. invest Derm., 82, 9-12 (1984).

Mokashi, S., Delikatny, E.J., and OrR. F.W., Relationship between chemotaxis, chemotactic modulators and cyclic nucleotide levels in tumor cells. Cancer Res., 43, 1980-1983 (1983).

O'Flaherty, J.T., Kreutzer, D.L., and Ward, P.A., Effect of prostaglandins $E_{1}, E_{2}$ and $F_{2 a}$ on neutrophil aggregation. Prostaglandins, 17, 201-210 (1979).

Orr, F.W., Varani, J., Delikatny, J., Jain, N., and Ward, P.A., Comparison of the chemotactic responsiveness of fibrosarcoma subpopulations of differing malignancy. Amer. J. Path., 102, 160-167 (1981).

Rivkin, I., Rosenblatt, J., and Becker, E.L., The role of cyclic AMP in the chemotactic responsiveness and spontaneous motility of rabbit peritoneal neutrophils: the inhibition of neutrophil movement and elevation of cyclic AMP levels by catecholamines, prostaglandins, theophylline and cholera toxin. J. Immunol., 115, 1126-1134 (1975).

SChOR, S.L., Schor, A.M., and BAZILl, G.W., The effects of fibronectin on the adhesion and migration of Chinese hamster ovary cells on collagen substrates. J. Cell Sci., 49, 229-310 (1981).

SChreY, M.P., and RuBIN, R.P., Characterization of a calciummediated activation of arachidonic acid turnover in adrenal phospholipids by corticotropin. J. biol. Chem., 254, 11234-11241 (1979).

Situ, R., LeE, E.C., McCoy, J.P., and Varani, J., Stimulation 
of murine tumor cell motility by laminin. J. Cell Sci., 70, 167176 (1984).

SkiPski, V.P., Peterson, R.F., and Barclay, M., Quantitative analysis of phospholipids by thin layer chromatography. Biochem. J., 90, 374-378 (1964).

Timpl, R., Rhode, H., Robey, P.G., Rennard, S.I., Foidart. J.M., and MARTIN, G.R., Laminin-a glycoprotein from basement membranes. J. biol. Chem., 254, 9933-9937 (1979).

VARANI, J., Chemotaxis. In: K. Honn and L. Marnett (eds.), Prostaglandins, leukotrienes and cancer, Vol. I, Biochemistry of arachidonic acid metabolism, pp. 227-241, M. Nijhoff, The Hague (1985).

Varani, J., and Fantone, J.C., Phorbol myristate acetate-induced adherence of Walker 256 carcinosarcoma cells. Cancer Res. , 42, 190-197 (1982).

Varani, J., Fligiel, S.E.G., and Perone. P., Directional motility in strongly-malignant murine tumor cells. Int. J. Cancer, 35, 559-564 (1985a).

Varani, J., Grimstad, I.A., KnibBs, R.N., Hovig, T., and McCoY, J.P., Attachment, spreading and growth in vitro of highly-malignant and low-malignant murine fibrosarcoma cells. Clin. exp. Metast., 3, 45-59 (1985).

Varani, J., Lovett, E.J., Elgebaly, S., Lundy, J., and Ward, P.A., In vitro and in vivo adherence of tumor cell variants correlated with tumor formation. Amer. J. Path., 101, 345-352 (1980).

Varani, J., Lovett, E.J., McCoy, J.P., Shibata, S., Maddox, D.E., Goldstein, I.J., and WiCHA, M., Differential expression of a laminin-like substance by high and low metastatic tumor cells. Amer. J. Path., 111, 27-34 (1983a).

Varani, J., Lovett, E.J., Wicha, M., Malinoff, H., and McCoy, J.P., Cell surface a-D-galactopyranosyl end groups: use as a marker in the isolation of murine tumor cell lines with varying malignant potential. J. nat. Cancer Inst., 71, 1281-1286 (1983b).

VARANI, J., ORR. W., and WARD. P.A., Comparison of subpopulations of tumor cells with altered migratory activity, attachment characteristics, enzyme levels and in vivo behavior. Europ. J. Cancer, 15, 585-592 (1979a).

VARANI, J., ORR, W., and WARD, P.A., Hydrolytic enzyme activities, migratory activity and in vivo growth and metastatic potential of recent tumor isolates. Cancer Res., 39, 2376-2380 $(1979 b)$.

Varani, J., and Perone, P., Response of Walker 256 carcinosarcoma cells to phorbol esters: possible regulation by prostaglandins. J. nat. Cancer Inst., 74, 165-172 (1985).

WerTZ, P.W., and Mueller, G.C., Rapid stimulation of phospholipid metabolism in bovine lymphocytes by tumor-promoting phorbol esters. Cancer Res. , 38, 2900-2904 (1978).

Wertz, P.W., and Mueller, G.C., Inhibition of 12-0-tetradecanoyl phorbol-13-acetate-accelerated phospholipid metabolism by 5,8,11, 14-eicosatetrynoic acid. Cancer Res., 40, 776-781 (1980).

Yamasaki, H., Weinstein, B., Fibach, E., Rifkind, R., and MARKS, P.A., Tumor promoter-induced adhesion of the DS19 clone of murine erythroleukemia cells. Cancer Res., 39, 19891994 (1979). 